\title{
Meditação sobre a noite: paisagem e fronteiras em $B R-3$
}

\author{
Angela Materno
}

É noite. E tudo é noite. Debaixo do arco admirável

Da Ponte das Bandeiras o rio

Murmura num banzeiro de água pesada e oleosa. $E$ En noite e tudo é noite. Uma ronda de sombras,

Soturnas sombras, enchem de noite tão vasta O peito do rio, que é como si a noite fosse água, Água noturna, noite líquida, afogando de apreensões As altas torres do meu coração exausto (...)

esse longo e belo poema de Mário de Andrade, intitulado A Meditação sobre o Tietê e datado de fevereiro de 1945 - mês e ano de sua morte, o que atribui ao poema, como observa Antônio Cândido, "um sentido quase misterioso de testamento" 1 - o rio figura o conflito, tantas vezes tematizado por
Mário em sua obra e em sua vasta correspondência, entre seu "aristocracismo de espírito" (como ele mesmo definia) e o destino que, voluntariamente, procurava cumprir: o de fazer uma "arte de circunstância" que, na contramão de seus ideais de escritor ${ }^{2}$ e de seu individualismo, ${ }^{3}$ pudesse ser "útil" e servir aos embates de seu tempo.

Meu rio, meu Tietê, onde me levas?

Sarcástico rio que contradizes o curso das águas E te afastas do mar e te adentras na terra dos homens,

Onde me queres levar?...

Angela Materno é professora do Departamento de Teoria do Teatro e do Programa de Pós-Graduação em Teatro da Unirio.

1 Este comentário de Antônio Cândido encontra-se em uma nota referente a uma carta de Mário a Carlos Drummond de Andrade, de 11 de fevereiro de 1945, na qual dá notícias do poema que está escrevendo: "Ando fazendo um poema chato, pesado, difícil de ler, duro nos ritmos, cadencial, bárdico, uma espécie de "Meditação sobre o Tietê" (Andrade, 1982, p. 245).

2 Em uma carta a Pedro Nava, datada de 24 de abril de 1926, Mário afirma: “(...) meu ideal é uma vida especializada num ramo só da arte, digamos música como estudo e literatura como criação e só. Saber do resto só pra enriquecimento lateral meu e não pra escrever sobre e no entanto escrevo tudo, dou alarma de tudo (...) É horrível Nava, porque meu destino, destino não, meu ideal não era ser assim. E sou e não desanimo um momento" (Andrade, 1982, p. 75).

3 No texto "O movimento modernista", escrito em 1942, em que reavalia o movimento artístico de 1922 e a sua própria trajetória, Mário declara: "Abandonei, traição consciente, a ficção, em favor de 
Eu me reverto às tuas águas espessas de infâmias,

Oliosas, eu, sofregamente, sujado

De infâmias, egoísmos e traiçôes.

$E$ as minhas vozes

Perdidas do seu tenor, rosnam pesadas e oliosas, Varando terra adentro no espanto dos mil futuros,

Destino, predestinaçôes...meu destino.

Estas águas

Do meu Tietê são abjetas e barrentas,

Dão febre, dão a morte decerto, e dão garças $e$ antiteses.

É a partir da escuta e da contemplação desse rio "às avessas", que se adentra pela terra escura e ávida dos homens, recolhendo suas luzes e assombros, que se desdobra a meditação do poeta. Sendo o Tietê, entretanto, não apenas objeto do poema, mas também ponto de vista, que "contamina" o timbre e o ritmo dos versos, assim como o próprio olhar sobre a cidade.

\section{(...) E a massa líquida}

Da multidão onde tudo se esmigalha e se iguala,

Rola pesada e oleosa e rola num rumor surdo,

E rola mansa, amansada imensa eterna, mas

No eterno imenso rígido canal da estulta dor.

É noite! é noite!... E tudo é noite! E os meus olhos são noite!

Eu não enxergo sequer as barcaças na noite.

Só a enorme cidade. E a cidade me chama e pulveriza,
Levado pelo Tietê, o poema também deságua, muitas vezes com sarcasmo, na paisagem política da cidade: na farsa dos "peixes grandes" - Peixes aos mil e mil, como se diz, brincabrincando / De dirigir a corrente, com ares de salvavidas - e na volumosa demagogia - Eu tenho medo... Meu coração está pequeno, é tanta / Essa demagogia, é tamanha / Que eu tenho medo de abraçar os inimigos (...). Tendo o rio Tietê como interlocutor, Mário revisita, neste poema final de sua vida, suas inquietações políticas e artísticas, dando voz, mais uma vez, ao seu medo e ao seu desejo "de ser multiplicado em multidão" (Andrade, 1981, p. 37).

Eu recuso a paciência, o boi morreu, eu recuso a esperança.

Eu me acho tão cansado em meu furor.

As águas apenas murmuram hostis, água vil mas turrona paulista

Que sobe e se espraia, levando as auroras represadas

Para o peito dos sofrimentos dos homens.

...e tudo é noite (...) (Andrade, 1987, p. 386-96).

Se no poema de Mário de Andrade, o rio, de certo modo, é a expressão poética de seu itinerário artístico e intelectual, no mais recente espetáculo do Teatro da Vertigem, dirigido por Antônio Araújo e concebido para ser apresentado no Tietê, o rio constitui o itinerário cênico dos atores e espectadores, que percorrem suas águas barrentas, e suas margens, para realizarem e assistirem às cenas de $B R-3 .{ }^{4}$

um homem-de-estudo que fundamentalmente não sou. Mas é que eu decidira impregnar tudo quanto fazia de um valor utilitário, uma valor prático de vida (...) Mas eis que chego a este paradoxo irrespirável: Tendo deformado toda a minha obra por um anti-individualismo dirigido e voluntarioso, toda a minha obra não é mais que um hiperindividualismo implacável! E é melancólico chegar assim no crepúsculo, sem contar com a solidariedade de si mesmo" (Andrade, 1974, p. 254).

4 O espetáculo BR-3, com concepção e direção de Antônio Araújo e dramaturgia de Bernardo Carvalho, estreou em São Paulo em 2006. Escritor premiado com o romance Nove noites (2002), Bernardo Carvalho é autor também, entre outros, dos romances Onze (1995), Teatro (1998) e Medo de Sade (2000). 
A travessia do rio refaz, teatral e ficcionalmente, a experiência de viagem que está na origem do projeto.Uma viagem por terra de São Paulo ao Acre, realizada pela equipe de criação do espetáculo. De Brasilândia (bairro pobre da periferia de São Paulo) a Brasiléia (situada na floresta amazônica e na fronteira do Acre com a Bolívia), passando por Brasília, a capital federal. Se estas três cidades, em função de seus nomes, parecem reiterar uma idéia de Brasil, suas realidades - vivenciadas pelo grupo por meio de oficinas de trabalho e de pesquisas - contradizem a unidade presumida e revelam as várias formas de percepção e de pertencimento à nação.

A dramaturgia de Bernardo Carvalho temporaliza esta extensão espacial percorrida, narrando a história de três geraçôes, de uma mesma família, que atravessam o território brasileiro numa rota simultaneamente de busca, de fuga e de banimento.

Grávida, Jovelina sai do nordeste em busca do marido, operário na construção de Brasília. Lá, em 1959, na chamada Cidade Provisória, ${ }^{5}$ descobre que ele morreu no canteiro de obras, deixando-lhe de herança uma mala e uma carta padrão, assinada pelo Presidente Juscelino Kubitschek, em que são convocados e enaltecidos os esforços e sacrifícios para a construção de Brasília. De posse da parca herança e do conselho / profecia da médium Zulema Muricy, que mais adiante será Tia Selma, Jovelina muda de cidade e de nome - embarca para São Paulo, Brasilândia, e passa a ser chamada de Vanda. A ser chamada, mas nunca vista, pois tornando-se a chefe do tráfico de drogas local - posto e negócios que herdou do segundo marido, também já morto -, faz da invisibilidade sua principal garantia de vida. Seus dois filhos Jonas, filho do operário, e Helienay, filha do traficante - também partem à procura de algo. Helienay busca, incessante e atormentadamen- te, um mapa, sem o qual não consegue encontrar nem o caminho de casa, nem a saída. Jonas, aflito com a possibilidade de ter herdado da mãe a invisibilidade - teme que ninguém consiga vêlo - e resistindo a substituí-la nos negócios, deixa-se converter por uma evangelista, tornandose um obreiro do Senhor. Depois do massacre de sua família, em função da disputa pelo controle do tráfico - que acaba ficando com um ex-policial, o Dono dos Cães - massacre no qual perde a mãe e a esposa, e pensa ter perdido seus dois filhos pequenos, Douglas e Patrícia, Jonas parte, nos anos 80 , para uma longa viagem pelo país, até onde ele termina, até os confins do Acre, em busca de uma visão, que lhe fora prometida pelo Pastor / Evangelista. Tentando ver, Jonas acaba fundando uma seita, e trocando o seu nome pelo de seu filho: passa a se chamar Mestre Douglas. Seus dois filhos, salvos do incêndio criminoso e separados por adoções diferentes, saem, dezessete anos depois, sem saberem um do outro, em busca do pai, depois de tomarem conhecimento de suas próprias histórias. Douglas, criado no estrangeiro e preparando-se para ser ator, vai ao encontro do pai no Acre. Patrícia, depois de fugir do reformatório onde estava internada, e de ser ludibriada pelo Dono dos Cães - o responsável pelo massacre e pela morte de sua mãe -, vai também para o mesmo local, para matar o homem que supostamente quer matar o seu pai e cuja descrição que lhe foi dada coincide com a de seu irmão. $\mathrm{O}$ encontro dos três no Seringal de Egito, no Acre, onde Jonas fundou sua religião, se dá em meio a um jogo fatal de travestimentos e equívocos. Golpes do destino, e de teatro.

Todas as buscas resultam em mortes. Empurrados para o extremo do país, Jonas, Douglas e Patrícia morrem quase fora do Brasil, quase exilados. Helienay morre louca. E Jonas/ Judas morrerá duas vezes. Enforcando-se num

5 A Cidade Provisória, criada em 1959, no início das obras, era uma das cidades-satélites onde residiam os operários, que nunca puderam morar no plano piloto, embora esta fosse a proposta inicial do urbanista Lúcio Costa, que projetou a cidade de Brasília juntamente com o arquiteto Oscar Niemeyer. 
Sábado de Aleluia, depois da morte de seus filhos, Jonas é confundido com um boneco, quando já morto, e à deriva, desce o rio numa jangada, pendurado como um Judas, e é então crivado de balas pelas pessoas que estão nas margens - "Não viram que ele não era um boneco!" relata a mulher de um senador, em uma das falas finais do texto, enquanto passeia com seu marido em um pedalinho em forma de cisne e, cenicamente, cruza com o barco-jangada de Jonas/Judas, sem vê-lo.

A história da família de Jonas é narrada em flashback pela ambígua personagem Evangelista, duplicada em Pastor e com ele se alternando ou se confundindo ao longo do espetáculo. Duas faces, ou melhor, face e voz de uma mesma e cindida figura, pois o Pastor é uma personagem só-voz, materializada numa fita de gravador. Evangelista narra para os espectadores, de dentro da balsa onde eles estão, a história de Jonas, enquanto aguarda ansiosamente a sua volta. É noite de Sábado de Aleluia em Brasilândia. A vigília comandada por Evangelista, e que inclui tal narração, é também a vigília pelo retorno de Jonas, o que não acontece. Sentindo-se como um Judas - "Tudo em que eu toco morre"6 - mas confundido, pelos outros, com sua versão inanimada, Jonas mata-se no rio num Sábado de Aleluia, e não ressuscita. Morre duas vezes.
Articulando ficção, registros de viagem e materiais de pesquisa, a dramaturgia de $B R-3$ tem como um de seus eixos temáticos a relação entre a organização social urbana brasileira e a proliferação de igrejas, templos e seitas. Ou ainda, a relação entre a criação de cidades - e de cidades dentro das cidades, pois multiplicam-se os dispositivos de segregação interna do espaço urbano $^{7}$ - e a fundação de religiōes. "Enquanto uns constróem uma cidade, os outros inventam uma religião", diz um vendedor a Jonas, em Brasília, já nos anos 80 , ao se referir ao Templo de Tia Selma, ex-Zulema Muricy, erguido na cidade. ${ }^{8} \mathrm{E}$ o espetáculo aborda o quanto tanto uma (a cidade) como a outra (a religião) podem ser, igualmente, impositivas - na delimitação dos lugares e dos papéis - e o quanto podem ser simultaneamente promissoras e massacrantes.

BR-3 tematiza também as relações entre profecias e cálculos de poder, visões e negócios, templos erguidos e vidas arruinadas. E parece apontar, ainda, para a coexistência, nada pacífi$\mathrm{ca}$, entre os mil planos e futuros anunciados para o país e a progressiva transformação do cotidiano nas grandes cidades (como Rio e São Paulo, por exemplo) em um "mundo de ação e reação, um mundo de cães”. É deste modo que a personagem o Dono dos Cães - ex-policial, dono de uma rinha de cães e de um bando de homens - define o mundo em que se vive, em

6 Todas as citações do texto do espetáculo, incluindo-se aí os títulos e a numeração das cenas, serão feitas a partir da versão final de Bernardo Carvalho.

7 Refiro-me aqui não apenas aos chamados dispositivos de segurança, tais como grades e cancelas - que controlam o acesso a prédios ou ruas, e os isolam em relação ao espaço comum da cidade - mas também à construção de condomínios e, atualmente, de verdadeiros condomínios-cidades (ou cidades muradas).

8 Bernardo Carvalho, no texto Eu vivo neste mundo, escrito a partir das observações e experiências da viagem feita com o Grupo Teatro da Vertigem, destaca "a lógica peculiar que garante uma igreja evangélica a cada esquina de Brasilândia e em cada povoado, por menor que seja, ao longo dos mais de quatro mil quilômetros percorridos (...) entre São Paulo e o Acre", e destaca também a "Disneylândia mística" que é Brasília, "celeiro das seitas mais ecléticas, que vão do alucinante Vale do Amanhecer a outras manifestações originais (...) Para completar, Brasiléia é o berço do Santo Daime, religião criada pelo mestre Irineu, ex-seringueiro e guarda territorial (...)" (Fernandes \& Audio, 2006, p. 31-2). 
um de seus diálogos finais com Evangelista /Pastor, de quem, afinal, era cúmplice.

Entranhado na cidade de São Paulo principal pólo econômico do país - e dela acumulando os detritos e descartes, o rio Tietê exibe, enquanto paisagem (e natureza) mortificada, o lixo, a febre e as antiteses do desenvolvimento urbano desordenado e especulativo. Neste sentido, o rio Tietê parece constituir em $B R-3$, assim como no poema de Mário de Andrade - só que sessenta e um anos depois, e não sei quantas vezes mais poluído - uma interlocução fundamental: percurso e horizonte, a partir do qual é encenado o confronto entre as cidades prometidas - por projetos, por políticos, por pastores e gurus - e as cidades (ou partes delas) esquecidas - periferias, lonjuras ou "incômodas" vizinhanças.

Estas duas cidades, tantas vezes sobrepostas, proliferam-se pelo país. E apontam, no caso das cidades prometidas, para as fantasmagorias de espaço e de futuro - o espanto, talvez, dos mil futuros - implicadas nas diversas formas de se ver o Brasil e dos Brasis se verem. E apontam, no caso das cidades (ou partes delas) esquecidas, para a configuração de territórios sitiados, pelo abandono e pela violência. Territórios limítrofes, geográfica e/ou socialmente, sobre cuja exclusão vêm sendo fundados, historicamente, no país, os projetos de crescimento econômico e os pactos políticos. Destinos e espaços de exceção que vêm se tornando a regra, na medida mesmo em que, há muito, estão previstos e inclusivamente excluídos.

\section{Paisagem noturna}

No Rio, $B R-3$ não foi apresentado em um rio, mas na baía. Na Baía de Guanabara. ${ }^{9}$ Foi aí que eu assisti ao espetáculo e é sobre a sua encenação nas águas da baía que farei meus comentários.

Embora também sofrendo os efeitos das agressōes ambientais, e também poluída, principalmente na rota escolhida para a apresentação do espetáculo ${ }^{10}$ - e o mau cheiro, em vários trechos, não deixa dúvidas quanto a isto - a bela Baía de Guanabara continua sendo um dos cartôes-postais da cidade, e este duplo estatuto de referência turística e de magnífica paisagem afeta a recepção de $B R-3$, produzindo especificidades e diferenças em relação à encenação no Tietê. Por outro lado, a enorme extensão de suas águas ${ }^{11}$, também pesadas e oleosas, faz com que, em meio a elas, a silhueta da cidade fique distante, assim como suas luzes e burburinho, o que intensifica a sensação de noite. De noite líquida e vasta.

Claro que as cidades avistadas da baía principalmente Rio e Niterói - são presenças fundamentais no espetáculo, embora não interfiram diretamente nele. Elas o cercam quase sempre de longe, piscam, pontuam a noite, contornam as águas e as cenas que aí ocorrem, e fazem desta distância o teor mesmo de sua presença.

Duas impressões são muito fortes para o espectador: a de que $\hat{E}$ noite. E tudo é noite, como insiste Mário de Andrade em seu poema, e a de que nosso olhar é tensionado por duas

9 BR-3 foi apresentado no Rio de Janeiro por ocasião da $8^{a}$ edição do Festival Internacional de Teatro Riocenacontemporânea, realizado de 4 a 14 de outubro de 2007 e cujo tema foi "Inventários: Bestiários, Dicionários, Imaginários". A temporada de BR-3 estendeu-se de 13 a 28 de outubro. Eu assisti ao espetáculo no dia 21.

10 A rota era a seguinte: do bairro do Caju à Ilha do Fundão, passando por debaixo da Ponte Rio- Niterói. As cenas aconteciam em 15 pontos distintos da Baía e também durante o percurso entre eles.

11 A Baía de Guanabara ocupa uma área de cerca de 380 quilômetros quadrados, o que inclui a superfície de suas ilhas, ilhotas e pedras, totalizando um perímetro de $131 \mathrm{Km}$. Essas informaçôes estão contidas no livro Baía de Guanabara: uma história de agressão ambiental de Victor Coelho (Rio de Janeiro: Casa da Palavra, 2007). 
modalidades de visão que pressupõem esforços distintos: ver as cenas e ver a paisagem.

Para assistir ao espetáculo $B R-3$, o público embarca ${ }^{12}$ em uma balsa coberta (denominada chata), mas aberta nas laterais, com capacidade para, aproximadamente, cem espectadores que, sentados em cadeiras giratórias, assistem às cenas que ocorrem, alternadamente, dentro da balsa onde eles estão, nas águas da baía - em voadeiras, em pequenas traineiras, numa plataforma flutuante, no barco rebocador ${ }^{13}$ e num pedalinho - e em determinados trechos ou margens, utilizados tanto em sua horizontalidade como em sua verticalidade. A última cena ocorre fora dos barcos e das águas - ela acontece em um casarão, na Ilha de Bom Jesus (na continuidade da Ilha do Fundão), onde se realiza o baile do Seringal do Egito, durante o qual morrem Douglas e Patrícia, sem que se saiba, ao certo, quem atirou em quem e quem atirou primeiro.

Muitas cenas acontecem em movimento, nos barcos que se deslocam paralelamente à balsa dos espectadores, em uma ou outra de suas laterais. Em alguns momentos do espetáculo, cenas ocorrem quase que simultaneamente nas duas laterais relativas à balsa. Em outros, o público apenas passa por determinada cena, ou imagem. Em outros ainda, a balsa vai em direção à margens (cenas), atracando e desatracando, ou seja, aproximando-se e afastando-se delas.

Esta oscilação das distâncias é constante em toda a travessia, o que desdramatiza o ritmo do espetáculo, possibilitando certos momentos de distensão do olhar que, por sua vez, e por isto mesmo, percebe-se dividido entre a focalização das imagens cênicas e o plano aberto da paisagem. Entre os recortes de luz - que são as cenas e as personagens - e um certo efeito de massa produzido pelas águas espessas e pela noi- te densa. Massa líquida e massa noturna, a partir das quais as cenas ganham forma e luz, permanecendo, entretanto, em tensão com o espaço difuso da paisagem noturna.

Se o ato de ver uma paisagem implica em um deslocamento do olhar por uma certa extensão e profundidade, ver uma cena teatral é, a princípio, concentrar o olhar numa determinada área, e ser atraído para o seu centro de luz. $\mathrm{Na}$ encenação de $B R-3$ na Baía de Guanabara, o olhar do espectador é, constante e alternadamente, atraído para as cenas e convidado a uma visão panorâmica, puxado para a luz e devolvido ao escuro. A noite cumpre aí, portanto, um duplo papel, como, aliás, tantas personagens da peça: o de ser a própria matéria da paisagem pois se trata de uma paisagem noturna, que acaba fazendo parte da experiência do espetáculo e o de ser um certo obstáculo à visão, já que os recortes da cidade e das próprias cenas ficam mais imprecisos. Se a noite problematiza o que se vê, ela é também, na encenação, aquilo que se vê, aquilo que aparece.

A experiência da noite redimensiona as noções de proximidade e de distância para além do princípio da extensão espacial. Ela é capaz de revelar, como observa Georges Didi-Huberman, a fragilidade dos objetos e sua vocação "a se perderem para nós quando nos são mais próximos" (Didi-Huberman, 1998, p. 99). No caso da encenação de $B R-3$ na Baía de Guanabara, portanto, a oscilação de distâncias produzida pelo próprio deslocamento do público e das cenas é acrescida do jogo noturno do próximo e do distante, intensificando-se as tensões visuais que o espetáculo produz. Tensões estas que, endossadas pelas ambigüidades e indeterminaçōes da narrativa, descartam qualquer viés ilustrativo no trato da temática urbana e do material do-

12 Antes, os espectadores eram transportados, em dois ônibus, do Centro Cultural Ação da Cidadania, no bairro da Saúde, até o bairro do Caju, onde ficava o local do embarque.

13 O rebocador era utilizado para deslocar e também para posicionar a balsa dos espectadores (chata) em relação às cenas. Algumas cenas também aconteciam nele. 
cumental que resultou do processo de pesquisa do grupo. E se pensarmos que $B R-3$ encena as diferentes formas de alguém se perder na cidade (Helienay), de perdê-la de vista, de se tornar nela invisível (Vanda), e de sonhá-la, percebemos o quanto esta paisagem noturna contracena com o espetáculo. E não só por ser uma interlocução relevante, mas também porque, enquanto paisagem, contraria e resiste ao movimento delimitador que, a princípio, é próprio ao enquadramento das cenas.

Ao analisar os exercícios paisagísticos, pictóricos e poéticos, Flora Süssekind chama a atenção não só para o esforço, aí presente, de "fixação, e concentração num espaço restrito, daquilo que se apresenta necessariamente como fluxo, variação (luz, atmosfera, estaçôes)", mas também para o movimento de "delimitação e singularização, contraditório com o que há de ilimitado, indivisível, descentrado, na noção mesma de natureza" (Süssekind, 1998, p. 215). No caso de $B R-3$, não se trata da tentativa de fixar a paisagem, nem de delimitá-la, mas sim de configurar o espetáculo em meio ao ilimitado e expondo-se a ele. Trata-se do esforço de singularizar cenas, atuações e imagens a partir do que é fluxo (por ser água e por ser paisagem) e, portanto, do que é inelutavelmente desfocado, descentrado.

As encenações de $B R-3$ no rio Tietê e na baía de Guanabara lidam com aspectos e desafios diversos. $\mathrm{O}$ rio tem percurso retilíneo e a baía é circular. Estes desenhos espaciais vinculam-se a diferentes percepções e experiências do tempo. À linearidade do rio corresponde, de certo modo, o percurso narrativo do espetáculo, que vai de um ponto a outro, no tempo e no espaço, embora este trajeto seja sempre visado pela instância da narração, que interrompe e entrecorta o fluxo dos episódios relatados. A forma circular problematiza, a princípio, a noção de direção, e conseqüentemente as referências de começo e de fim. Ela pressupóe a recorrência. Se na Baía de Guanabara esta circularidade do espaço resiste, em parte, à linearidade da narrativa, esta também aponta, entretanto, em função de suas ambivalências e da própria duplicação de nomes e de papéis que opera, para uma certa imprecisão do sentido (no sentido, inclusive, de direção), na medida em que ao trocarem de identidade, as personagens descontinuam o seu caminho ao mesmo tempo em que nele prosseguem - elas, de certa forma, recomeçam.

A encenação no Tietê - hoje transformado em um verdadeiro esgoto a céu aberto - trabalha com o paradoxo de um fluxo estagnado, e remete às relaçôes entre rio e morte, evocando a imagem de um Lete urbano, ${ }^{14}$ que carrega a morte em seu próprio leito (cadáveres de animais, restos de tudo, putrefaçóes) e atravessa o inferno da grande metrópole. Aliás, mesmo na encenação na Baía de Guanabara é forte e insistente esta imagem de uma travessia para a morte - que é, aliás, uma das faces da viagem empreendida por Jonas -, até porque são várias as cenas em que, num pequeno barco, varam a noite apenas duas personagens, sendo o barqueiro uma delas.

Se no rio Tietê a cidade fica mais próxima (dos atores e dos espectadores), e suas luzes e tráfego constituem a "porção empírica" que interfere no espetáculo - como interlocução e como "ruído" -, na baía de Guanabara, a cidade fica mais distante e é a noite, principalmente, que atua como entorno e interferência, "disputando" e forjando o olhar do espectador. Nos dois espaços, entretanto, percebe-se a elaboração de uma visualidade tensionada simultaneamente pelo excesso de "informação" e pelo obscurecimento (pois tanto a noite pode ser uma experiência visual "excessiva", quanto o excesso de coisas a ver, ou a distrair nossa atenção,

14 Na mitologia grega, rio Lete (o rio do esquecimento) é um dos rios do Hades (mundo subterrâneo, relacionado às entranhas da Terra, às trevas e, por isto, ao inferno. ). O barqueiro Caronte é quem, mediante pagamento, atravessa as almas pelos rios até o Hades. 
pode ser obscurecedor), assim como pela constante ameaça de dissolução das imagens e das vozes no que há de difuso e incontrolável, tanto na paisagem-natureza quanto na paisagem urbana de uma grande metrópole. E pela ameaça, também, de não realização do próprio espetáculo, em função das condições ou previsões meteorológicas. Tensionamentos espaciais e cênicos que possibilitam um desdobramento da perspectiva do espectador para além do próprio deslocamento físico pelas águas da baía.

\section{Imagem e Tempo}

O contato com a noite - com seu volume e com seu negrume - torna-se, então, elemento determinante na recepção de $B R-3$ na Baía de Guanabara. É desse fundo obscuro que, de modo barroco, surgem as personagens e as cenas. E é para ele que elas tendem. Tendem a desaparecer.

Gilles Deleuze, no livro A dobra: Leibniz e o Barroco, destaca que "Tintoretto e Caravaggio substituem o fundo branco de giz ou de gesso, que preparava o quadro, por um fundo sombrio marrom-vermelho", o que faz com que as coisas e cores brotem "do fundo comum que testemunha sua natureza obscura" e que as figuras definam-se "pelo seu recobrimento mais do que pelo seu contorno", pois no Barroco "o claro não pára de mergulhar no escuro” (Deleuze, 1991, p. 54-5).

A fragilidade dos contornos - tensionados pelo problemático enquadramento num espaço extenso, fluido e noturno, e pelos problemas de escala que daí decorrem - atribui às cenas de $B R-3$ um caráter de esboço ou de ruína, de inacabamento ou de sobrevivência. $\mathrm{O}$ que, aliás, está indicado no próprio percurso da narrativa - da Cidade Provisória ao fim do mundo - tal como ele é designado no interior mesmo do texto, nas falas das personagens: "Foge da vingança. Vai embora, para bem longe. Vai atrás de onde começa o fim do mundo. De onde você só poderá ver o fim do mundo. Onde já não dá para saber se é o fim ou o começo. Até onde termina este país. Até não se lembrar mais de quem foi. E lá você verá”, recomenda Evangelista / Pastor a Jonas, em um bilhete, logo após o massacre de sua família.

As construçôes ou dispositivos cenográficos são, em sua maioria, abertos, vazados, ou apenas parcialmente fechados ao fundo, deixando sempre visíveis porçôes de noite ou de água. Somente a cena que se passa no casarão, já no final do espetáculo, ocorre em espaço inteiramente fechado. Configura-se portanto em $B R-3$ uma oscilação visual entre construção e demolição. Ainda em relação a este caráter de ruína das imagens cênicas, vale destacar aqui a observação do iluminador Guilherme Bonfanti a respeito de seu próprio trabalho neste espetáculo (tendo em vista a encenação no Tietê). Guilherme destaca que seu projeto de iluminação acabou sendo pautado e viabilizado por materiais e equipamentos "que estão fora de circulação, que um dia foram modernos e que hoje são os mais arcaicos", equipamentos já em desuso, "verdadeiros dinossauros que vão contra todos os conceitos de modernidade na luz" (Fernandes \& Audio, 2006, p. 86). E afirma ter encontrado aí, no lixo, no que foi deixado de lado ou jogado fora, a "chave" de sua criação.

Se, por tudo o que foi comentado até aqui, a luz é fundamental e difícil neste espetáculo, é bastante significativa a presença deste anacronismo na materialização visual de uma encenação que teve como mote inicial " aprofundar um estudo sobre o Brasil contemporâneo, que já surgia em certos momentos do espetáculo anterior, Apocalipse 1,11" (Fernandes \& Audio, 2006, p. 90), como afirma a assistente de direção Eliana Monteiro, que assumiu também a co-direção do espetáculo no Rio de Janeiro. Meios arcaicos, já em desuso e em extinção, foram utilizados, portanto, para iluminar, literalmente, cenas construídas e escritas a partir de vivências atuais nas cidades brasileiras. Configura-se aí, me parece, nesta opção e nesta observação do iluminador, uma interessante relação entre imagem e tempo, estando ambos implicados em uma operação anacrônica. 
Recusado pelas concepções historicistas ou idealistas da história como aquilo que contamina a pura imagem do passado, ou do presente, o anacronismo consiste, entretanto, numa categoria inerente à própria experiência do tempo e da história, e também aos seus objetos e imagens. Se nenhum "agora" é simples e nenhum presente é plenamente sincrônico a si mesmo, "o anacronismo atravessa todas as contemporaneidades", como afirma Georges DidiHuberman (Didi-Huberman, 2000, p. 15), e assinala não apenas a heterogeneidade de ritmos e tempos presente em cada época, mas também o trabalho dialético das imagens.

Para Didi-Huberman, a própria visualidade é uma categoria anacrônica do tempo, pois diante de uma imagem, por mais atual que ela seja, o passado não cessa de se configurar, pois a imagem só se torna pensável a partir de um trabalho da memória. E diante de uma imagem antiga, por mais antiga que ela seja, o presente não cessa de se constituir, pois é a partir dele que a olhamos (Didi-Huberman, 2000, p. 10).

Em $B R-3$, o recurso ao arcaico - em relação às possibilidades técnicas atuais de iluminação - para projetar o historicamente recente cria uma tensão temporal na própria produção da imagem, configurando cenas que, embora próximas, pelas referências históricas e vivências atuais de que são feitas, chegam aos espectadores com uma "textura", digamos assim, evocativa, como se surgissem de uma remota proximidade.

Ao qualificar os equipamentos utilizados como "verdadeiros dinossauros", Bonfanti alude a uma certa "pré-história" da iluminação, da qual eles seriam uma espécie de fósseis, restos (ruínas) de outro tempo, que sobreviveram, não só porque duraram mas também porque foram "desenterrados" neste tempo - "Fui remexer nos teatros e nas empresas", diz Guilherme, aludindo à dimensão arqueológica de seu processo de criação. Na imagem do fóssil também está indicada a sobrevivência do passado no presente e, portanto, a simultaneidade do não simultâneo.

Esses equipamentos considerados arcaicos, mas talvez nem tanto assim, só são assim designados porque a modernidade, ao produzir incessantemente o novo, também produz aceleradamente o arcaico. O dia em que "foram modernos" pode ser quase ontem. Em nossa experiência do tempo, e o tempo é uma experiência historicamente transformável, o outrora não é longe. E neste sentido, há que se desconfiar tanto do fetiche do contemporâneo (quando as atualidades tecnológicas e midiáticas acionadas para representá-lo cumprem apenas a função de produzir um imediato reconhecimento do tempo presente e uma absoluta aderência a ele) quanto do fetiche do "primitivismo" (quando a ancestralidade, entendida como origem, como gênese, é evocada para assinalar uma permanência não problemática das coisas e concepções, ou uma suposta natureza do homem e do mundo que se impõe às transformações históricas). No caso de $B R-3$, não se trata nem de uma coisa, nem de outra. Nem da idéia de que o passado ilumina o presente, como se a relação entre eles fosse meramente contínua e causal. Trata-se, me parece, do esforço de constituir uma perspectiva dupla e contraditória para as imagens cênicas. A relação do outrora com o agora é dialética, diz Walter Benjamin: "não é uma progressão, e sim uma imagem, que salta" (Benjamin, 2006, p. 504-5).

As concepções de luz e de encenação de $B R-3$ conferem às cenas um caráter de "aparições”, não na acepção ilusória do termo, mas no sentido mesmo da imagem como aquilo que "salta", que aparece, não para produzir uma evidência, mas para fulgurar a sobrevivência daquilo "que cai", ou seja, do que está prestes a desaparecer. A imagem podendo, então, ser pensada como aquilo que sobrevive - como resto, fóssil ou lampejo - de um desaparecimento, ou extinção.

\section{Natureza e História}

A encenação de $B R-3$ produz belos instantes em que imagens, às vezes quase pictóricas, passam por nós, espectadores, enquanto nós também 
passamos. E passam por nós de um modo, às vezes, quase cinematográfico: como quadros em movimento. Com a diferença de que nós também passamos. Digo "quase cinematográfico" porque o espetáculo provoca a sensação de uma "paisagem atravessada", tal como Jacques Aumont denomina as experiências tanto do passageiro de trem quanto do espectador de cinema, similares em vários aspectos, e superpondo-se, de modo exemplar, no fato, destacado por Aumont, de que "o cinema fará da locomotiva sua primeira estrela" (Aumont, 2004, p. 54). Em $B R-3$, os espectadores são "viajantes", mas não imóveis - deslocam-se com a balsa e giram nas cadeiras. E muitas vezes também se levantam, para ver melhor, ou caminham pela balsa. O que eles vêem, entretanto, como já foi dito, não é um espetáculo totalmente enquadrado, como pelas janelas de um trem ou pela tela de cinema.

O espetáculo produz e pressupõe o movimento de uma paisagem atravessada tanto fisicamente quanto ficcionalmente, já que a narrativa trata de uma travessia pelo território brasileiro, tematizado também a partir de suas paisagens transformadas historicamente, seja no que diz respeito às agressões, poluições e mortificações da natureza, seja no que se refere às reconfigurações espaciais efetuadas. Colocandose em evidência, portanto, as próprias tensões entre espaço urbano e paisagem. O espetáculo fala de florestas devastadas e expropriadas de sua madeira (cena de Brasiléia), de matas transformadas em cemitérios, em locais de desova de cadáveres (cena da Mata da Cantareira, em Brasilândia) e de paisagens alteradas por projetos urbanísticos (Brasília)

$\mathrm{Na}$ cena 2, "Construção de Brasília, 1959”, por exemplo, a médium Zulema Muricy anuncia e descreve, do barracão onde dá consultas, a cidade que projetará o país no futuro e realizará o seu sonho de modernidade, "do qual participarão as árvores, os arbustos e o descampado como complementos naturais, pois o que caracteriza o conceito moderno de urbanismo (...) é, precisamente, a abolição do pitoresco, graças à incorporação do bucólico ao monumental". 15

Mais adiante na narrativa, quando Zulema Muricy já será Tia Selma, fundadora de uma religião em Brasília (numa citação ao Vale do Amanhecer, de Tia Neiva, uma das inúmeras seitas existentes nesta cidade), a problematização da natureza resultará não da construção efetiva de uma cidade, mas das projeções do imaginário e, neste momento, as indeterminaçôes da paisagem coincidem com a oscilação dos nomes e das designações. É a seguinte a resposta de um vendedor a Jonas, em Brasília, quando este indaga sobre a proveniência de uma música que está ouvindo: "Você chama isso de música? Mas não é. Vem do vale depois daquela serra. Chamam de serra mas não é serra. Também não é vale. Uma mulher que não gostava do nome fundou uma religião do outro lado. Inventou um relevo. Disse que era serra. Disse que era vale. Eles repetiram. Agora todo mundo a chama de Tia Selma. Mas quando eu era menino, ainda se chamava Zulema. Zulema $\mathrm{Mu}-$ ricy. E tinha horror do nome.Foi no tempo em que aqui ficava uma outra cidade. Que também tinha outro nome. Era onde morava quem tinha vindo para a construção. Enquanto uns constroem uma cidade, os outros inventam uma religião. Você devia ir ver com os próprios olhos".

Entre as paisagens atravessadas pelo espetáculo, está o próprio rio Tietê, para o qual $B R-3$ foi pensado, e que no limite extremo de poluição - como natureza mortificada e "petrificada” - torna-se quase um grande fóssil, que

15 Foi da coletânea de artigos Com a palavra Lúcio Costa, organizada por sua filha Maria Elisa Costa, que Bernardo Carvalho extraiu alguns trechos para compor a fala de Zulema Muricy, "no fascinante processo de deslocamento e superposição de camadas ficcionais e reais que compõe a dramaturgia de BR3" (Fernandes \& Audio, 2006, p. 45). 
corta a cidade de São Paulo exibindo a face "préhistórica" da atualidade.

Ainda no âmbito de uma paisagem atravessada, há uma bela "seqüência" no espetáculo, quando o percurso de Jonas pelo país, nos anos 80 , é materializado em uma longa lista de nomes próprios - de pessoas, de cidades ou de estabelecimentos destas cidades - que Jonas vai citando, enquanto se desloca num pequeno barco pelas águas da baía, acompanhado pela balsa dos espectadores, que segue paralelamente ao barco de Jonas - "Paulínia, Jaguariúna, Araras, Borracharia Dois Irmãos, Leme, Pirassununga, Atacadista América, Cravinhos, Motel Happy End, Ribeirão Preto, Jardinópolis, Orlândia, São Joaquim da Barra, Guará, Ituverava, Igarapava, Supermercado Paraíso (...) Rua da Goiabeira, Dr. Dada, Dona Adanta, Ivonete, Argentino moto táxi, zona Beco da Maringosa, Chá Chá de Anum, Arigó, Gislaine Salva Tierra, Seu Bibiliano, Beirute, Denise Cosméticos, Play Time, Igreja Cristo do Aviamento, Materiais Sol Nascente, Supermercado Futuro (...)”.

Nesta travessia-inventário, que vai aportar na Igreja dos Mortos (cena 20), é como se a personagem Jonas percorresse o rio/rua (ou a baía) lendo as placas, cartazes e outdoors espalhados pelo caminho, ou como se desenhasse verbalmente o mapa de uma viagem: a viagem realizada pelo grupo. De qualquer modo, da série de nomes próprios enunciados, o espectador retém, principalmente, a sonoridade das palavras e uma ou outra curiosidade nos nomes, ou na junção deles. Mas é capaz de imaginar as histórias e experiências contidas em cada nome mencionado.

Cito, então, um fragmento de Passagens, de Walter Benjamin, fragmento que é uma citação de Leo Spitzer recolhida por Benjamin para propor uma teoria sobre os nomes de ruas. Fragmento que, a meu ver, poder ser lido à luz desta cena, ou vice-versa. Diz ele: "Sobre a teoria dos nomes de ruas. 'Os nomes próprios, também, têm um efeito sem peso conceitual, puramente sonoro (...). Os nomes próprios são, para usar uma expressão de Curtius (p. 65) 'for- mulários em branco' que Proust pode preencher com sensações e sentimentos, porque ainda não foram racionalizados pela língua' (Leo Spitzer, Stilstudien, vol. II, Munique, 1928, p. 434)" (Benjamin, 2006, p. 560).

Ainda em relação aos nomes próprios, pode-se dizer que não apenas os nomes das cidades ou bairros - Brasília, Brasilândia e Brasiléia - constituem pontos, localizações, no mapa narrativo traçado por $B R-3$. Os nomes das personagens assinalam, igualmente, lugares e posições no percurso temporal encenado. Em cada local ou posicionamento ocupado, a mesma personagem muda de nome. E como tais posicionamentos variam, as personagens estão destinadas a heteronomia: - "Seu nome será sempre outro" diz Zulema Muricy a Jovelina, que mais adiante serão Tia Selma e Vanda.

As questôes que instigaram o projeto de $B R-3$ parecem referir-se, fundamentalmente, a uma geografia. Dizem respeito a problemas do espaço: posicionamentos, proximidades e distâncias, relações entre o dentro e o fora, entre intimidade e estranheza. E dizem respeito a problemas de espaço: de convivência, de vizinhança, de isolamento, de banimento. Tanto a viagem empreendida pelo Brasil quanto os palestrantes convidados para os seminários que foram organizados - geógrafos, arquitetos, sociólogos, antropólogos e historiadores - parecem apontar para uma reflexão sobre os impasses da organização social do espaço urbano brasileiro. E para os vários espaços - imaginários ou não, econômicos e culturais, físicos e políticos, que convivem, bem ou mal, dentro de cada um deles. Heterotopias que o espetáculo procura flagrar e encenar.

Encenada em um espaço de passagem, o rio, esta complexa geografia foi historicizada (temporalizada) pela narrativa. E se o barco, como propõe Michel Foucault no texto Outros espaços, "é um pedaço de espaço flutuante, um lugar sem lugar (...) fechado em si e ao mesmo tempo lançado ao infinito mar", ele se torna, por isto mesmo, em nossa civilização, "a heterotopia por excelência” (Foucault, 2005, p. 422). 


\section{Cortes e Planos}

BR-3 enfatiza, de vários modos, uma horizontalização da perspectiva do espectador. Não só em função do deslocamento do público e de parte das cenas pela superfície das águas, mas também em função da linha narrativa do espetáculo, que projeta pontos sucessivos na trajetória da família de Jovelina. Este eixo horizontal é, entretanto, cortado pela verticalidade de algumas cenas. Como, por exemplo, a cena 2 - "Construção de Brasília, 1959" - que, na verdade, é o primeiro trecho ao qual os espectadores chegam (a cena 1 ocorre dentro da balsa em que estão e corresponde à fala inicial de Evangelista).

Esta segunda cena, impactante em função dos contrastes que produz, ocorre sob a Ponte Rio-Niterói, onde é erguido um andaime de ferro, sobre o qual os operários trabalham e respondem às indagações de Jovelina, que chega numa voadeira à Cidade Provisória, procurando pelo Congresso e pelo marido, que supostamente estaria trabalhando em sua construção. À fragilidade de Jovelina naquele pequeno barco, acompanhada apenas pelo barqueiro e deslocando-se pelas extensas e noturnas águas da baía, contrapõe-se não só a verticalidade da armação em ferro, mas também a ampliação sonora do espaço, obtida por meio dos efeitos de eco e de coro que as falas dos operários produzem. A mesma frase é repetida por diferentes atores, seguidamente, como se fosse o eco de uma mesma voz, ou conjuntamente, numa espécie de coro.

De um modo ou de outro, há uma proliferação de vozes, advindas da cidade em construção, que contrasta com a voz solitária de Jovelina em busca de uma única informação: o local onde fica o Congresso. E sobre esta Brasília fictícia, e ainda inacabada, os espectadores vêem e ouvem o tráfego de veículos na ponte que liga o Rio a Niterói. Uma constelação de cidades, apenas parcialmente vistas ou sugeridas, e interligadas pela distância que as separa, surge então diante dos olhos e da imaginação dos espectadores.
Mais adiante, na cena 7, "Brasilândia. Casa de Vanda. Década de 80", é Vanda/Jovelina quem ocupará o plano alto - agora, uma outra armação figura o esboço de um barraco, aonde se chega por meio de uma escada elevada. Se na cena 2 o eixo vertical forja a imagem, ou a miragem, de uma cidade - e de um futuro - em construção, na cena 7 a verticalidade aponta para a invisibilidade e o isolamento dos quais Jovelina torna-se refém, ao assumir, em Brasilândia, o controle do tráfico de drogas.

Se a verticalidade é associada, a partir do Renascimento, à experiência da contemplação, ou seja, ao campo visual - a tela ou o quadro colocados verticalmente diante do pintor e do observador - experiência esta tensionada, por exemplo, pelas pinturas e gestos pictóricos de Jackson Pollock, a horizontalidade costuma ser relacionada ao campo da escrita, às suas linhas. Mas esta configuração da escrita passa também a ser tensionada, por exemplo, pela própria experiência do espaço urbano. Em um dos fragmentos de Rua de mão única, Walter Benjamin comenta o processo de verticalização da escrita nas cidades: "Se há séculos ela havia gradualmente começado a deitar-se, da inscrição ereta tornou-se manuscrito repousando oblíquo sobre escrivaninhas, para afinal acamar-se na impressão, ela começa agora, com a mesma lentidão, a erguer-se novamente do chão. Já o jornal é lido mais a prumo que na horizontal, filme e reclames forçam a escrita a submeter-se de todo à ditatorial verticalidade" (Benjamin, 1987, p. 28).

Em outro de seus textos, Sobre a pintura ou: Signo e Mancha, Benjamin estabelece diferenças entre a pintura e o desenho, associando a primeira à mancha e às cores, e o segundo, ao signo e às linhas, e portanto à horizontalidade. Ao analisar as linhas gráficas do desenho - e aí podemos incluir a cartografia - Benjamin observa que essas linhas determinam a superfície e dela dependem, pois só há linha gráfica sobre um fundo e em relação a ele, de tal modo que "um desenho que recobrisse inteiramente seu fundo deixaria de ser um desenho" (Benjamin, 2000, p. 173). 
De certa forma, portanto, pode-se dizer que as tensões que $B R-3$ estabelece com a superfície das águas poluídas, do rio ou da baía, e com o fundo obscuro a partir do qual as cenas são recortadas, contribuem também para uma horizontalização da perspectiva do espectador.

De vários modos, então, os planos e cortes verticais e horizontais interagem em $B R-3$. À horizontalidade da viagem por terra (referente ao processo de pesquisa do espetáculo) e da viagem pela água (referente à encenação) corresponde a presença do mapa (da linha gráfica) como um dos elementos temáticos e estruturais da dramaturgia. Mas outro elemento também aí relevante é o espelho, que remete o espectador para as questôes da imagem e da visualidade, e contrapóe ao mapa o labirinto.

\section{Topografias e Espelhamentos}

A trama de BR-3 é construída com fios duplos, partidos ou sobrepostos. O que atribui à história encenada uma mobilidade de perspectiva semelhante àquela que a própria encenação imprime ao olhar do espectador, ao deslocá-lo numa balsa. Por meio de espelhamentos, duplicações, trocas de nomes e de papéis, o texto se constitui como estrutura instável, produzida por um duplo movimento. Por um lado, o de topografar a experiência da viagem e da pesquisa, traçando relações de distância e de proximidade entre lugares, acontecimentos e personagens, e esboçando uma certa visão de Brasil. Por outro, o movimento de captar, digamos assim, a inquietante estranheza das impressões e situações mapeadas, buscando apreender as fantasmagorias - de cidade e de futuro, de pátria e paternidades - que estão implicadas nos diversos modos de se ver e de se perder de vista o país. Inquietante estranheza que, oticamente, os espelhos podem produzir, e que literariamente tem sido muito tematizada. Entre os vários efeitos especulares ficcionalmente narrados, há, por exemplo, os que colocam em xeque a identidade de uma personagem, quando a ausência de reflexo no espelho exibe não apenas o vazio de sua superfície, mas também a angústia de quem se sente desapropriado da própria imagem - não devolvida -, e portanto exilado de si mesmo. Citando-se, aqui, entre outros, os contos $O$ espelho, de Machado de Assis, e $O$ espelho, de Guimarães Rosa.

Há um momento em $B R-3$ em que Jonas, diante de um pequeno espelho pregado na parede, pergunta para Helienay, pensando, a princípio, em sua mãe: "Por que é que ninguém vê uma pessoa?" e prossegue, "E eu ? Você está me vendo? Diz que está me vendo!" Esta sensação de invisibilidade leva-o a querer ver, a perseguir uma visão prometida e a fundar uma religião, Agnóia.

A dramaturgia é construída a partir dessas tensões entre contrários e das ambivalências daí decorrentes. Um jogo de duplos, de espelhos e de alteridades constitui a narrativa. Além da duplicidade de nomes e de designações Jovelina/Vanda, Zulema Muricy/Tia Selma, Evangelista/Pastor, Jonas/Douglas, Jonas/Judas - outros "pares", de natureza e de função distintas no texto, podem também ser apontados, como por exemplo: pastor e pecuarista, ambos envolvidos com rebanhos e negócios, surdez e alucinação auditiva (a médium Zulema Muricy, que "responde a quem pergunta", tem problema auditivo, já o Dono dos Cães ouve latidos que ninguém mais ouve: "É por isso que agora eu me cerco deles. Pelo menos tenho a certeza de que existem", diz ele), vidência e invisibilidade ("Eu gosto de ver os corpos, porque eles não me vêem" diz Patrícia, referindo-se aos cadáveres entre os quais se esconde), ver para crer e crer para ver ("Nunca viram a senhora. Começaram a desconfiar. Só acreditam vendo", diz Edimilson a Vanda, sugerindo que ela prove que existe; "No fundo, todo mundo quer acreditar" diz Evangelista à platéia).

O espetáculo e a dramaturgia de $B R-3$ são também construídos a partir da relação entre mapas e espelhos, entre localizações e miragens. Entre superfícies - mapas e corpos (e Helienay pede para Jonas desenhar um mapa em seu cor- 
po, num desejo de orientação e de intimidade) - e espaços virtuais. E se o mapa denota um território existente, o espelho, segundo Foucault, produz uma experiência mista, entre a utopia e a heterotopia - "O espelho, afinal, é uma utopia, pois é um lugar sem lugar. No espelho, eu me vejo lá onde não estou, em um espaço irreal que se abre virtualmente atrás da superfície". Mas o espelho é igualmente uma heterotopia, pois embora existindo efetivamente, e tornando o lugar que ocupo, quando nele me olho, absolutamente real, é a partir dele "que me descubro ausente no lugar em que estou porque eu me vejo lá longe" (Foucault, 2005, p. 415).

E se os mapas traçam uma relação espacial entre pontos diversos, fazendo das escalas e dos códigos cartográficos elementos fundamentais ao seu conteúdo informativo sobre o mundo físico, os espelhos apresentam o mundo das aparências, captando-as em suas variaçôes. E como "não é possível cartografar as aparências” (Gombrich, 1987, p. 193), a relação entre espelhos e mapas em $B R-3$ produz tensões na narrativa.

As ambigüidades já começam na primeira cena, quando Evangelista/Pastor recebe os espectadores no local do embarque e diz que sonhou com eles, sonhou com febre. Sonhou que eles viriam - "Achei que vocês estivessem aqui, diante de mim. Achei que fosse um rio (está diante do rio) Achei que tudo se passava aqui." Os espectadores estão em Brasilândia, num sábado de Aleluia, e há uma guerra, "Ninguém lê os jornais? Não sabem que há uma guerra?", e então Evangelista /Pastor conduz o público para a balsa, que é também um espaço duplo: uma igreja que era, antes, uma sala de cinema, da qual restaram as poltronas forradas de vermelho ( as cadeira giratórias destinadas ao público) e os filmes na cabeça de Evangelista.

Pistas múltiplas, e a oscilação entre elas, orientam, ou desorientam, a perspectiva da platéia em relação ao relato sobre a história de Jonas. Evangelista diz estar em vigília pela Páscoa e pelo retorno de Jonas, que saiu de Brasilândia há dezessete anos. Mas diz também que faz dezessete anos que ela está dormindo, e aconselha os espectadores a fazerem o mesmo para se acostumarem com a guerra - "Basta pensar que estão sonhando".

Na primeira cena de $B R-3$, Evangelista diz que ficou no lugar do Pastor - "Faz dezessete anos que o pastor caiu bem aqui, crivado de balas, e até agora não mandaram ninguém no lugar dele. Eu faço o que posso. Ponho a fita. Pelo menos, é a mesma voz. É a voz do pastor". Na última cena, no pátio do casarão (na ilha de Bom Jesus), repete-se esta fala inicial, mas como se quem falasse fosse o Pastor - "Tive um sonho esta noite. Sonhei com vocês. Achei que viriam. Achei que vocês estivessem aqui, diante de mim. Achei que fosse um rio. Achei que tudo se passava aqui", e acrescenta: "Antes havia uma evangelista. Ela caiu bem aqui".

Em uma das últimas cenas que ocorrem na balsa-platéia, Evangelista, conforme indicado na rubrica do texto, "de repente louca, transformada, assume o papel do Pastor" e diz a si mesma: "Basta eu me ausentar, basta eu ter negócios para resolver fora, e você transforma o mundo num filme e esta igreja num cinema (...) Eu não disse que a imagem é a besta?”. Em seguida, o Dono dos Cães, que havia retirado a fita - com a voz do pastor - do gravador, coloca a fita cassete na boca de Evangelista para calála e, depois, puxa a fita como se puxasse sua língua. Nesta mesma cena, o Dono dos Cães, depois de dar a notícia da morte de Jonas no Acre, diz a Evangelista: "Ele está morto, Evangelista. Você não quer enxergar? Ainda não entendeu que a gente é feito da mesma matéria? Somos a nova Santíssima Trindade. Eu, você e o pastor. Faz anos que aqui já não é um cinema. Pare de sonhar".

Entre a vigília e o sono, entre o sonho e o despertar - outras fronteiras atravessadas pelo espetáculo, e a partir das quais a saga da família de Jovelina é narrada - entre filme e realidade, a platéia é "conduzida" por um narrador cindido ("Também sou uma mulher partida", "Tem um homem desesperado na minha cabeça”, diz Evangelista). O próprio elemento noturno, 
também inerente à dramaturgia em sua referência aos universos onírico e fílmico - "A aura da obra fílmica é noturna” (Aumont, 2004, p. 118) - produz zonas de indiscernibilidade, nas quais os contornos das personagens e de suas relações não ficam inteiramente nítidos. Isto ocorre, principalmente, nas cenas que acontecem na balsa dos espectadores, que são determinantes para a estruturação dramatúrgica de $B R-3$.

Estas cenas interrompem, em diversos momentos, o fluxo narrativo da história de Jonas para focarem a situação e o contexto problemáticos de sua narração. Nelas, em grau mais acentuado do que em outras cenas do espetáculo, sugere-se uma oscilação entre diversos pontos de vista - do sonho, do delírio, da realidade e de sua suposta ou possível fusão com imagens fílmicas. Nas cenas que acontecem no mesmo espaço em que o público está, ocorre também uma "dramatização" da própria narração, já que o Dono dos Cães e Evangelista /Pastor disputam a autoria do relato. Em determinado momento, O Dono dos Cães reinvindica: "Também quero dar meu testemunho. Essa história não é sua. Como é que você conta uma história se não sabe o final?". Ao que Evangelista, nervosa, reponde: "A história está na minha cabeça".

Em função da importância dramatúrgica destas cenas, em certo sentido desestabilizadoras da linearidade narrativa, me parece que elas foram pouco trabalhadas, cenicamente, em suas diferenças e especificidades em relação às demais. A justaposição de espaços, vozes e personagens não foi, talvez, suficientemente materializada no espetáculo. Com isto, deixou-se mais à mostra a continuidade da narrativa do que as suas descontinuidades. As cenas que acontecem na balsa dos espectadores são as que estão, simultaneamente, mais próximas (fisicamente) do público e mais distantes (em termos de nitidez "ficcional"). São, portanto, cenas que tematizam, de certo modo, as próprias condições de enunciação do espetáculo, pois produzem "ruídos" e oscilações na percepção da platéia. Daí também a sua importância. Não quero dizer com isto que as ambigüidades presentes nessas cenas não sejam percebidas pelo público, mas essas cenas poderiam ser, talvez, mais estruturantes no espetáculo.

Se duplicações e espelhamentos ocorrem no percurso narrativo, eles também acontecem no percurso cênico. Se vários são os momentos em que o barco dos atores e a balsa dos espectadores seguem paralelos um ao outro, como que duplicados, em um desses momentos forja-se uma cena única no espetáculo, em que o jogo de luzes, sombras e reflexos produz uma bela e surpreendente imagem. Em seu trajeto pelo país, e pela baía, Jonas, em seu pequeno barco, passa diante da lateral do enorme e escuro casco de um navio ancorado, cujo nome é Di Gregório. Esta seria uma outra cena - além daquela que ocorre, já no final, no casarão - em que o fundo estaria totalmente fechado, pois é muito extensa e alta a lateral do casco do navio, se comparada com a dimensão do barco de Jonas. Entretanto, em função do interessante jogo de luz que aí se dá, este fundo também se abre, pois nele são projetados reflexos azulados da água e a sombra de Jonas, e de seu barco. Um jogo de sombras - soturnas sombras - duplica Jonas mais uma vez.

\section{Ficção e Encenação}

Evocando o topos barroco do mundo como teatro, são várias as cenas no espetáculo em que o tema da criação ou fundação de novos espaços - cidades, seitas, religiōes - associa-se ao da distribuição ou redistribuição de papéis a serem representados.: "Crie um novo papel para si. Somos todos atores e atrizes de Deus" diz Zulema Muricy a Jovelina, ao aconselhá-la a ir para São Paulo. É também Zulema Muricy quem anuncia: "A verdade é que dentro de alguns anos eu também construirei uma cidade onde só havia deserto e solidão; a verdade é que eu também ressuscitarei ao longo dessas novas vias, onde cada um poderá imaginar um novo papel para si (...) a verdade é que eu também imagino uma arquitetura que irá conferir à cidade um 
caráter irreal (...) Onde só havia deserto e solidão, erguerei o templo." E no templo de Tia Selma, os fiéis vestem-se como princesas, fadas, gladiadores - cada um escolhe seu papel, entre os disponíveis, mas não pode transgredi-lo.

Em Cobija, o outro nome - o outro lado do rio - de Brasiléia, a rainha Mariana Helena Cristina, uma doente de lepra, fabrica dinheiro e um reino imaginários: extremamente maquiada, constrói, com pedaços aleatórios de enfeites e de imaginação, seus trajes e sua história. No baile do seringal do Egito, onde Jonas fundou sua religião, os novos participantes, os que chegam pela primeira vez, não podem ver - têm as cabeças cobertas por sacos de papel e, na dança, fazem o papel das moças, pois no baile só entram homens.

Se ao longo do espetáculo os rostos são às vezes máscaras, os corpos, adereços, e os espaços, relevos inventados, é porque a travessia de Jonas por cidades e por igrejas, em busca da visão, é também uma travessia por inúmeras visões, e versões, de origem, de fim, ${ }^{16}$ de país e de futuro. Uma travessia por espaços fictícios ("Disse que era serra. Disse que era vale. Eles repetiram.”), por relações teatralizadas ("Qual vai ser o seu papel hoje?”, pergunta a Jonas uma mulher vestida de princesa, no templo de Tia Selma), por imaginários deslanchados (o Império Incaico da rainha Mariana Helena Cristina, que unifica "a Bolívia ariana, o Brasil e a África”) e por imaginários capturados (a cena em que o convencimento religioso ao qual Jonas é submetido é figurado como um cativeiro).

A construção ficcional da dramaturgia de $B R-3$ "contracena" com esses territórios "ilocali- záveis", que são parte (significativa) das realidades experenciadas pelo teatro da Vertigem em seu percurso de viagem e de pesquisa pelo Brasil. Territórios ilocalizáveis no sentido de não coincidirem totalmente com seus contornos, de não constituírem propriamente pontos em um mapa, mas feixes, sombras ou vazios. Ilocalizáveis porque multiplicados em espaços outros, ou porque subtraídos aos parâmetros mínimos de determinação. Ilocalizáveis, portanto, em vários sentidos. Seja porque são, no caso de algumas seitas, uma justaposição de referências espaciais, temporais e religiosas distintas - como a fusão, no ritual do Santo Daime, de fetiches patrióticos com catolicismo, com danças de inspiração indígena e africana e consumo de bebida alucinógena ${ }^{17}$, ou uma mistura, como na seita do Vale do Amanhecer, do culto a Diana com o candomblé. ${ }^{18}$ Seja porque são, no caso das moradias de Brasilândia, uns amontoados de barracos sobre montanhas de mata e de lixo, como relata Ivan Delmanto (Fernandes \& Audio, 2006, p. 52), e no caso dos moradores de Brasilândia, porque são pessoas muitas vezes incapazes de localizar, no mapa do país, a região em que suas famílias nasceram, como destaca Sílvia Fernandes (Fernandes \& Audio, 2006, p. 42).

Territórios e habitantes ilocalizáveis, seja porque expropriados da própria língua, como no caso dos adolescentes de Jardim Paulistano que, mesmo estando na escola, são incapazes de escrever, de relatar por escrito suas experiências ou idéias, como observa Bernardo Carvalho ao se referir à oficina de criação de textos por ele oferecida (entre outras que o Teatro da Vertigem realizou em Brasilândia), seja porque muitas ve-

16 Se a fundação de cidades (abordada no espetáculo) remete à tematização da origem, as religiōes tentam "dar conta" do fim, de modo geral suspendendo-o.

17 Conforme descrito por Bernardo Carvalho no texto "Eu vivo neste mundo" (Fernandes \& Audio, 2006, p. 32).

18 Observação feita também por Bernardo Carvalho no texto "Eu vivo neste mundo". Ivan Delmanto, em "Diário de expedição", cita o seguinte trecho de um dos ritos do Vale do Amanhecer: "Rei de Esparta, unificaste o Reino de Apolo em Cristo Jesus. Unimos as nossas forças. Rufam os tambores" (Fernandes \& Audio, 2006, p. 113). 
zes abandonados em cidades praticamente inexistentes, sem escolas, sem saneamento básico e com moradias absolutamente precárias, como no caso da cidade de Assis Brasil e de parte da cidade de Rio Branco, ambas no Acre. ${ }^{19}$

É a partir dessas realidades ilocalizáveis que a dramaturgia de $B R-3$, tensionando mapas e espelhos, rearticula as instâncias da realidade, do fictício e do imaginário, presentes na própria matéria temática referida e produzida pelo espetáculo. Se o fictício e o imaginário são disposiçōes antropológicas que se manifestam em nossa vida cotidiana - nas diversas formas de se constituir visões e versões de mundo (não como puras invençôes, mas como modos de lidar e de confrontar-se com a realidade, e portanto a ela relacionados) - o que diferencia a ficção literária, como observa Wolfgang Iser, ${ }^{20}$ é seu dispositivo de autodesnudamento, ou seja, a indicação de sua própria ficcionalidade (o "como se") por meio da encenação do discurso. Nesse sentido, o "como se" da ficcionalidade literária não seria um procedimento ilusório, nem propriamente representacional (no sentido de re-apresentar algo já existente, previamente dado), mas sim um operador da encenação do discurso, na medida em que aciona uma oscilação contínua entre presença e ausência. A autoindicação da ficcionalidade faz com que toda presença produzida sinalize, também, uma ausência. Encenação sendo aí concebida, portanto, como a aparição daquilo que não pode estar presente, como aparição daquilo que se ausenta. Deste modo, diferentemente do que ocorre, por exemplo, na experiência da evidência, na encenação (tal como está sendo entendida aqui, em sua pertinência ao jogo ficcional) o objeto e sua aparição são descolados um do outro.

É como uma "travessia de fronteiras" que Iser conceitua a ficção literária, compreendida como um modo de articular a realidade a partir de uma forma específica de interação com o imaginário. As fronteiras transgredidas dizem respeito, por um lado, aos mundos referenciais simultaneamente evocados e suspensos pela ficcionalidade do texto, e por outro, à forma que esta atribui ao imaginário - a princípio difuso - ao ativá-lo. A realidade não é, portanto, abolida do texto ficcional, nele permanece, nele se repete, mas como designação negada (e não como referência dada). É o paradoxo da presença de designações negadas que ativa o imaginário. $\mathrm{O}$ jogo ficcional produz, portanto, e ao mesmo tempo, a irrealização da realidade e a realização do imaginário, tendo ambos - realidade e imaginário - seus limites transgredidos, não no sentido de uma transcendência, mas no sentido de uma encenação.

BR-3 tematiza o território brasileiro (no sentido amplo do termo território) a partir, principalmente, da relação entre geografia urbana e ordenamento religioso. Cada cidade (estação) pela qual passa o público aponta para uma determinada forma desta relação. No espetáculo,

19 Refiro-me aq-ui às descrições e observações feitas por Ivan Delmanto no texto "Diário de expedição" (Fernandes \& Audio, 2006, p. 116-9).

20 Refiro-me aqui às teorizaçôes e análises contidas nos livros O fictício e o imaginário. Perspectivas de uma antropologia literária, de Wolfgang Iser, e Teorias da ficção. Indagaçôes à obra de Wolfgang Iser, organizado por João César de Castro Rocha. Recorro a Iser para pensar a construção ficcional não somente como a elaboração de uma história, mas como uma operação que implica a realidade e o imaginário, e que se diferencia, enquanto forma específica de ficção, de outros modos e usos do fictício. Assim sendo, apesar de Iser analisar a noção de ficção literária a partir, fundamentalmente, de romances e de narrativas, estarei considerando a ficção literária como abrangendo também a ficção dramática - como o faz, em ouro contexto de análise, Käte Hamburger, no livro A lógica da criação literária (São Paulo: Perspectiva, 1975) - sem, é claro, desconsiderar as diferenças de estrutura, meios e modos artísticos entre o texto narrativo e o texto teatral. 
Brasília também emerge das miragens e profecias de Zulema Muricy; Brasilândia, constituída pelo lixo, pela mata / cemitério da Cantareira e pelo reduto dos cães, é o teatro da guerra (do tráfico) e o lugar da evangelização aprisionante de Jonas; Brasiléia, com seus índios e árvores exterminados, é o lugar dos ritos / bailes de morte; Cobija é figurada a partir do território imaginário da rainha Mariana Helena Cristina (e é sobre uma plataforma flutuante em meio às águas da baía que esta cena é realizada); a Igreja dos Mortos confunde-se com a cidade fundada pelos escravos fugitivos, pois mesmo as almas e corpos penados precisam de um lugar para morar. ${ }^{21}$

Em $B R-3$, as realidades referenciais trazidas para o texto e para a cena passam a ocupar posiçōes, funções e relações distintas daquelas das quais foram extraídas. O espetáculo não designa, portanto, aqueles territórios. Não sendo designados, os territórios estão, entretanto, presentes no espetáculo, não como referências duplicadas, mas como possíveis mapas para uma percepção crítica dos modos de territorialização e de designação das realidades.

\section{Corpo e Território}

Outro território tematizado em $B R-3$ é o corpo, abordado no espetáculo como parte de uma geografia humana e política. Território em que se entrecruzam, portanto, vida, poder, morte e o paradoxo de uma exclusão inclusiva, ou seja, aquilo que Giorgio Agamben considera e analisa como a estrutura do estado de exceção. ${ }^{22}$

Adereçados ou animalizados, os corpos em $B R-3$ remetem quase sempre a formas inorgânicas, mortificadas ou coisificadas, sejam elas agir como um cão (o Dono dos Cães), ser malhado como um boneco (Jonas/Judas), ser duplicado em um objeto, um gravador (Evangelista/Pastor), ou sobreviver entre cadáveres (Patrícia). Se a cena final do espetáculo se passa em Brasília, no Congresso, o discurso que aí se ouve é o da defesa dos animais silvestres. Diz o senador: "O tráfico de animais silvestres, ao contrário de outros tráficos, é cruel porque lida com vidas (...)”.

Corpos mutilados (Zulema/Tia Selma não tem os braços) ou imobilizados (Jonas, amarrado e vendado, é convencido pela voz do Pastor a fugir da vingança, sentir Jesus e erguer um templo) também são vistos durante a travessia pela baía de Guanabara, assim como os corpos inertes das imagens-adereços que passam flutuando. Em alguns momentos, os atores usam máscaras que ampliam desproporcionalmente o rosto e evidenciam o artifício.

Entre figurinos (de princesa, de fada, de gladiador ) e cadáveres (Vanda diz só ver corpos para onde quer que olhe, e Evangelista, logo na primeira cena, ao referir-se à guerra em Basilândia, diz ao público: "Não olhem para trás. Depois eles tiram de lá os corpos que ficaram"), a tematização do corpo em $B R-3$ parece também ecoar, de certo modo - e mesmo que de um modo bem específico e particular - a idéia

21 A Igreja dos Mortos, no espetáculo, parece ser uma referência à cidade Vila Bela da Santíssima Trindade, em Matogrosso, cidade que, como informa Ivan Delmanto no texto "Diário de Expedição", foi abandonada pelos latifundiários quando a capital do estado transferiu-se para Cuiabá, e passou a ser habitada apenas pelos escravos fugitivos. Até 1970, ainda segundo Delmanto, Vila Bela era habitada exclusivamente por negros (Fernandes \& Audio, 2006, p. 114-5).

22 Nos livros Homo Sacer: o poder soberano e a vida nua I e Estado de exceção Agamben analisa histórica e conceitualmente a lógica e a estrutura do estado de exceção, e reflete sobre as formas por meio das quais ele vem se tornando a regra, inclusive nas democracias ocidentais, "ainda que, eventualmente, não declarado no sentido técnico". Segundo o autor, "Diante do incessante avanço do que foi definido como uma "guerra civil mundial", o estado de exceção tende cada vez mais a se apresentar como o paradigma de governo dominante na política contemporânea” (Agamben, 2004, p. 13). 
e a imagem da "vida matável". ${ }^{23}$ "Vida matável” que se materializa não só nas inúmeras referências a mortos ao longo do espetáculo, ${ }^{24}$ como também na indagação - "Matar índio é crime?” - feita por um seringueiro a Pedro Biló, fiscal ambientalista. Esta indagação é insistentemente repetida pelo seringueiro, e ouvida durante toda esta cena que se passa em Brasiléia. O seringueiro quer fazer uma denúncia, mas antes precisa saber se matar índio é crime. Acaba, entretanto, sem obter nem a resposta nem a atenção do fiscal.

"Vida matável" enfocada também em outros espetáculos recentes, como em Os Sertôes, concebido e dirigido por José Celso Martinez Corrêa, com o Teatro Oficina Uzyna-Uzona, a partir do livro homônimo de Euclides da $\mathrm{Cu}$ nha, que descreve o massacre da população de Canudos, e em Apocalipse 1,11, espetáculo anterior do Teatro da Vertigem, que abordava o massacre dos presos no presídio do Carandiru, em São Paulo

No livro Homo sacer, Agamben refere-se à vida insacrificável mas matável do homo sacer, uma complexa e contraditória figura do direito romano arcaico, na qual a vida humana é incluída no ordenamento júridico sob a forma de sua exclusão. O homo sacer (o homem sacro), segundo fontes pesquisadas pelo autor, era aquele que, julgado pelo povo por um delito, não poderia ser sacrificado - não poderia ser levado à morte pelos ritos do sacrifício - mas poderia ser mor- to por qualquer um, e este ato não seria punido, não seria criminalizado. Agamben analisa este conceito-limite do direito romano como uma estrutura de dupla exclusão. Pois se o sacrifício era o dispositivo que realizava a passagem de algo do âmbito do profano para o âmbito do sagrado, o veto do sacrifício significava uma exclusão da esfera do direito divino, e a impunidade de sua morte significava uma exclusão da ordem do direito humano.

Fora (e dentro) da ordem jurídica normal estava também o soberano, definido como aquele que, em situações emergenciais, poderia decidir sobre o estado de exceção, ou seja, poderia, legalmente, suspender a ordem jurídica (a lei). Analisando essas duas figuras - a do homo sacer e a do soberano - como simétricas e correlatas (ambas implicadas em um paradoxo topológico), Agamben constrói, a partir desta correlação, a hipótese de que esta seria uma relação política originária, ou seja, "o primeiro paradigma do espaço político do Ocidente" (Agamben, 2002, p. 16). Sua aposta analítica é a de que "se é verdadeiro que a figura que o nosso tempo nos propõe é aquela de uma vida insacrificável, que, todavia, tornouse matável em uma proporção inaudita, então a vida nua do homo sacer nos diz respeito de modo particular" (Agamben, 2007, p. 121).

Tendo como uma das interlocuções fundamentais de seu livro as análises de Foucault sobre a biopolítica, ou seja, sobre a crescente implicação da vida nos mecanismos e cálculos

23 Emprego aqui uma expressão (e uma noção) utilizada e desenvolvida por Giorgio Agamben em Homo Sacer: o poder soberano e a vida nua I, mas que será desdobrada no contexto específico desta análise do espetáculo BR-3. As análises de Agamben sobre a "vida matável" e sobre o estado de exceção - formuladas tendo em vista os campos de concentração, as chamadas "guerras civis legais" e a situação mundial pós-11 de setembro - me parecem também pertinentes para refletirmos, por exemplo, sobre o modo como muitas vezes são pensadas e majoritariamente aplicadas, no Brasil, as políticas de segurança questão fortemente em jogo nas tematizações atuais da cidade (e $B R-3$ é uma delas) e que diz respeito às relações entre violência e direito.

24 E que vai produzindo uma espécie de conjunto ou coletivo de mortos, sintetizado, de certa forma, na cena da Igreja (Cidade) dos Mortos, onde um crente diz a Jonas: "Os escravos fugitivos fundaram esta cidade. Eram como as almas. Tinham que morar em algum lugar. Todo mundo sempre constrói uma cidade (...) Tem morto na família? Entra. Eu te prometo os teus mortos.” 
de poder, ${ }^{25}$ Agamben procura pensar de que modo a progressiva coincidência do espaço da "vida nua" (a vida dos viventes, a vida biológica, esta que se torna matável) com o espaço político - "A nossa política não conhece hoje outro valor (e, conseqüentemente, outro desvalor) que a vida" - coincidiu também com uma expansão da lógica da exceção, lógica na qual se inscreve o homo sacer.

Se os espetáculos anteriores do Teatro da Vertigem, que constituíram a Trilogia Bíblica, ${ }^{26}$ abordavam as tensões entre o sagrado e o profano, em $B R-3$, se alguma sacralidade permanece, é esta - não religiosa - do homo sacer. Sacralidade relacionada não a uma separação (sagrado, no sentido religioso, significa separado, isto é, subtraído ao uso livre e comum, e consagrado aos deuses), mas a uma lógica de exceção. Sacra, neste sentido, é a vida matável.

A exceção, como analisa Agamben, é uma forma de exclusão inclusiva, pois aquilo que está sob o estado de exceção (e não sob o estado de direito) não é simplesmente excluído, mas "capturado fora" (conforme, aliás, a própria etimologia da palavra exceção). O que caracteriza a exceção "é que aquilo que é excluído não está, por causa disto, absolutamente fora da relação com a norma; ao contrário, esta se mantém em relação com aquela na forma da suspensão. A norma se aplica à exceção desaplicando-se, retirando-se desta" (Agamben, 2007, p. 25). Não se trata, portanto, de uma pura ausência da lei, da norma ou do Estado (de direito), mas de uma presença e vigência esvaziadas. Não é que eles não estejam presentes em determinado território, ou situação, mas eles daí se retiram: e esta é uma forma de manter-se em relação. O vigor da lei consistindo, então, nesta capacidade de manter-se em relação com uma exterioridade. No estado de exceção vigora, portanto, a "força da lei” sem lei, ou seja, a relação de abandono, de bando, de banimento ( $\mathrm{E}$ a travessia de Jonas é também uma rota de banimento).

Ainda segundo Agamben, "A sacralidade da vida, que se desejaria hoje fazer valer contra o poder soberano como um direito humano em todos os sentidos fundamental, exprime, ao contrário, em sua origem, justamente a sujeição da vida a um poder de morte, a sua irreparável exposição na relação de abandono" (Agamben, 2007, p. 91).

Pode-se dizer, então, que o corpo insacrificável mas matável é um corpo "territorializado", na medida em que nele se inscrevem as tensões e paradoxos entre o dentro e o fora, entre inclusão e exclusão, entre fronteiras e zonas de indistinção. Em $B R-3$, os corpos situam-se, predominantemente, nestas zonas de indiferença e de trânsito contínuo entre o vivo e o cadáver, entre o corpo e o objeto, entre o homem e o animal (como, por exemplo, na cena de sexo entre Helienay e o Dono dos Cães, figurada como uma cópula animal), apontando, assim, para a necessária tematização, nas reflexões atuais sobre o corpo, desta percepção de que dele também fazem parte os diversos dispositivos (discursos, tecnologias, instituições etc.) que o forjam e o capturam, e na relação com os quais operam-se os processos de subjetivação e de dessubjetivação. Para além das concepções essencialistas do humano, é preciso considerar que o corpo, cada vez mais, inclui essas zonas de passagem para as coisas, objetos, mercadorias, e para a condição de cadáver e de criatura.

25 Diz Foucault em História da sexualidade I: a vontade de saber: "O homem, durante milênios, permaneceu o que era para Aristóteles: um animal vivo e, além disto, capaz de existência política; o homem moderno é um animal, em cuja política, sua vida de ser vivo está em questão" (Foucault, 1979, p. 134).

26 O Paraíso Perdido, O Livro de Jó e Apocalipse, 11. Os comentários mais específicos sobre a relação de $B R-3$ com os espetáculos anteriores do Teatro da Vertigem serão feitos na última parte do texto: $B R-3 \mathrm{e}$ a Trilogia. 
É preciso considerar, por um lado, que um homem é um homem, na acepção irônica que Brecht atribui a esta expressão na peça que a tem como título, e na qual se diz que um homem pode ser desmontado e remontado como um automóvel, e por outro, que "Nada se parece menos com um homem do que um homem”, boutade que Balzac atribuiu a George Brummell. ${ }^{27}$

\section{$B R-3$ e a Trilogia}

Um dos aspectos que tem singularizado a premiada trajetória do Teatro da Vertigem é a escolha de determinados espaços urbanos (espaços social e institucionalmente emblemáticos) para neles, e a partir deles - ou seja, requisitando e confrontando-se com sua materialidade e semântica - conceber e realizar as encenações. Nos espetáculos anteriores, O Paraíso Perdido (1992), O livro de Jó (1995) e Apocalipse 1,11 (2000), que compõem a denominada Trilogia Bíblica, a escolha recaiu sobre espaços fechados: uma igreja, um hospital e um presídio (esses dois últimos desativados), respectivamente. Além de fechados, esses três espaços, na sucessão em que foram escolhidos, remetem, progressivamente, à idéia e à experiência mesmo de encarceramento. Tanto assim, que todos os espetáculos terminavam com o gesto cênico de abrir as portas, para que o público ao fim, e enfim (dado o forte e intencional desconforto físico que $O$ livro de Jó e Apocalipse 1,11, por exemplo, produziam), respirasse o ar das ruas.
Em BR-3 as "portas" estão abertas desde o início. A própria cidade (ou parte dela) - sua noite, suas luzes, seus ruídos e movimento - foi o espaço escolhido. Realizar o espetáculo neste espaço aberto, noturno, fluido (rio ou baía), descentrado e difuso produziu diferenças significativas e interessantes na rota artística até então seguida pelo Teatro da Vertigem. Não apenas em função do espaço, certamente, mas também do modo como a encenação de Antônio Araújo dele se apropria e nele interfere, e em função também da dramaturgia. Em BR-3 o Teatro da Vertigem trabalha com um outro tipo de intensidade, diferente daquela que tem sido a sua marca. Uma intensidade menos afirmativa, não paradigmática, entendendo este adjetivo tal como Roland Barthes o conceitua no livro O Neutro. O paradigma, segundo o autor, "é a oposição de dois termos virtuais dos quais atualizo um, para falar, para produzir sentido" (Barthes, 2003, p. 17). Paradigmático seria, então, aquilo que se constitui a partir de um binarismo, de uma oposição conflitante, da afirmação de um termo (marcado) contra o outro (não marcado). Paradigmático seria, portanto, o que evidencia uma distinção, uma separação, de onde provêm o conflito, a escolha e o sentido (no caso, um certo modo de construir e de lidar com o sentido). ${ }^{28}$

Intensidade paradigmática, tal como estou tentando pensá-la aqui, seria aquela que mobiliza o conflito progressivamente, trabalhando pouco as variaçôes, gradaçôes e nuances (que são componentes das intensidades). Uma intensidade não paradigmática seria aquela que

27 A menção a esta frase, a esta boutade, encontra-se no capítulo "Beau Brummell ou a apropriação da irrealidade" do livro Estâncias de Giorgio Agamben (Belo Horizonte: UFMG, 2007, p. 86). A tradução de Selvino José Assmann mantém o termo em francês (provavelmente está assim no original, em italiano).

28 Para Barthes, neutro é tudo aquilo que burla o paradigma, que o desfaz ou contraria. Diferentemente, entretanto, do modo como esse termo costuma ser entendido e usado no âmbito do senso comum, o neutro, para Barthes, não remete à indiferença, à ausência de posicionamento, nem ao achatamento das intensidades, até porque, segundo ele, "burlar o paradigma é uma atividade ardente, candente" (Barthes, 2003, p. 19). Não estou aqui considerando, entretanto, que toda intensidade não paradigmática remeta ao neutro. 
diminui "a superfície de contato do sujeito com a arrogância do mundo (e não com o mundo)" (Barthes, 2003, p. 409). O que não significa que as intensidades paradigmáticas sejam arrogantes, mas sim que elas produzem menos fissuras, menos esgarçamento nos impulsos imperativos dos gestos e das falas. A própria língua, como observa Barthes, é, a princípio, assertiva, e para matizar o discurso é preciso brigar o tempo todo com ela (Barthes: 2003, p. 94).

No caso dos espetáculos da Trilogia Bíblica, a atribuição de significado cênico ao ato de abrir as portas no final evidencia uma separação, que se já não é mais aquela que existe entre o espaço do mundo e o espaço teatral, é uma separação que parece delimitar certo modo performático, uma teatralidade "fechada" em uma trajetória muito demarcada, e contínua, que termina quando as portas se abrem (penso aqui, mais especificamente, em Apocalipse 1,11).

A narrativa bíblica é uma das fontes ocidentais do mito, e este implica em uma concepção do tempo e dos acontecimentos como predeterminados, predestinados. Os mitos atribuem sentido à existência, mas a concebem como um percurso inescapável. Ao historicizar as imagens e o texto bíblicos com a violência cotidiana e banalizada de nossa era midiática, e com a violência extremada e sem sentido das chacinas e massacres urbanos, o espetáculo Apocalipse 1,11 mantém, entretanto, a estrutura mítica como suporte da recepção. O espectador faz também, de certo modo, um percurso inescapável: é conduzido firmemente pelas sa- las e corredores do presídio, quase como um detento (mas ele logo percebe que este "quase" não será ultrapassado), enquanto cenas, gestos e imagens cada vez mais violentos acumulamse diante dele, numa progressão praticamente ininterrupta, "fechando" e "imobilizando" a sua perspectiva, e produzindo, de certa forma, uma evidenciação da violência. A própria dramaturgia, ao se constituir, principalmente, como uma sobreposição de referências histórico-contextuais aos elementos e figuras míticas (do Apocalipse), e não tanto como uma problematização mútua desses dois campos referenciais a partir de seu confronto, acabou também contribuindo, a meu ver, apesar da multiplicidade de referências e de citaçôes que aciona, para este movimento de reduplicação.

O trabalho dos atores em Apocalipse 1,11, e nos espetáculos anteriores, revela uma atuação engajada, tecnicamente muito preparada, e corajosa no enfrentamento dos limites físicos e da auto-exposição radical. Por isto mesmo, o trabalho dos atores produzia, também, uma "sacralização" da própria atuação, que apresentava, inclusive, um traço sacrificial (penso aqui em $O$ livro de Jô e Apocalipse 1,11). Neste sentido, essa intensa proximidade física entre ator e espectador gerava, simultaneamente, uma marcada distância ente eles, advinda dessa sacralização da performance atorial, já que sacralizar é uma forma de separar, de indisponibilizar algo ou alguém ao acesso comum. ${ }^{29}$

Em $B R-3$, os atores (e a encenação) lidam com outro modo de intensidade e de exposição.

29 Refiro-me aqui ao modo como Giorgio Agamben conceitua as noçōes de sagrado e de profano no ensaio "Elogio da profanação", incluído em seu livro Profanaçâes. Segundo o autor, se o sagrado (no sentido religioso do termo) é aquilo que é separado da esfera humana e subtraído ao uso comum, profanar significa restituir algo ao livre uso dos homens. Neste sentido, não há religião sem separação (pois todas implicam em algum modo de sacralização) e seria justamente isto que a determina, e não a idéia habitual de que religião significa "religar" (o termo religio, segundo o autor, não deriva de religare mas de relegere). É a partir daí que Agamben faz uma distinção entre profanar e secularizar (operação que não necessariamente desativa o "modelo sagrado" ou as "forças religiosas" de separação), retomando e desdobrando um fragmento de Walter Benjamin intitulado "O capitalismo como religiāo". 
Se o espetáculo, como já comentado anteriormente, trabalha com as constantes oscilações entre proximidade e distância (na relação entre cena e espectador), construção e diluição (na relação entre elementos cenográficos e espaço), aparecimento e desaparecimento (na relação entre imagem cênica e paisagem noturna), os atores cujos corpos também oscilam e transitam entre o orgânico e o inorgânico, entre o humano e o animal - estão expostos à própria fragilidade da atuação, e não à sua força. E isto é bastante interessante, e forte. Fragilidade que não se refere, aqui, à capacidade interpretativa dos atores, mas ao confronto com as condições de atuação. Condições produzidas pela própria proposta cênica do espetáculo e pelos desafios aí colocados.

O corpo a corpo com um rio quase morto, com a paisagem noturna de uma metrópole ou de uma imensa baía, com o contínuo deslocamento pelas águas, e com a possibilidade de ver a atuação ser engolida pela cidade - já que é com sua abertura e com sua dispersão que os atores contracenam - aponta para tensões concretas, e artísticas, entre o teatro e o espaço urbano.

Sintomática, neste sentido, é a observação feita pela atriz Daniela Carmona, ao relatar sua sensação durante os primeiros ensaios no Tietê: "tudo no rio é imenso, ficamos minúsculos, é assustador" (Fernandes \& Audio, 2006, p. 71). O espanto de Daniela parece referir-se a um certo apagamento da presença dos atores na relação com o espaço urbano escolhido. Apagamento que se torna, no espetáculo, não uma condição inelutável, e nem uma condição a ser superada. Mas sim, um limite a ser trabalhado, e desdobrado, pela cena. A estratégia de confronto com as condições de atuação e de encenação não parece ter sido a de "dominar o espaço" apesar das dificuldades, mas sim a de fazer desta fragilização possível de ocorrer, dessa singularização difícil da performance atorial e cênica, o modo mesmo de abordar as tensões e paradoxos entre fronteiras e zonas de indistinção, estejam estas tensões na paisagem urbana e social brasileira, ou na paisagem difusa da noite líquida da baía de Guanabara.
Em $B R-3$, os corpos estão, sobretudo, "travestidos". Sejam estes travestimentos o de Patrícia, ao disfarçar-se de homem para entrar no baile do Seringal do Egito, ou os travestimentos dos adeptos da seita do Vale do Amanhecer, ou o mapa que se sobrepóe ao corpo de Helienay, ou a máscara utilizada pelo Dono dos Cães para enganar Patrícia. Ou ainda, as trocas de nome das personagens, que podem ser pensadas, também, como formas de travestimento. E se há no espetáculo, portanto, uma problematização dos nomes próprios, há também uma focalização dos corpos "impróprios", ou seja, dos corpos dissociados de sua "própria forma”. Elemento circunstancial, necessário, mas ao mesmo tempo significativo no espetáculo é o colete salva-vidas, anexado ao corpo e ao figurino dos atores (os coletes dos espectadores ficam atrás de suas cadeiras). Avolumando os corpos e alterando seus contornos, o colete salva-vidas expõe a fragilidade daquilo que ele protege e encobre.

Mário de Andrade, em suas viagens etnográficas pelo Brasil, como ele as denominava, registrou suas experiências e impressões em uma espécie de diário de viagem. São notas e apontamentos reunidos sob o título $O$ turista aprendiz. Entre as anotações sobre sua viagem pelo rio Amazonas até o Peru, há a seguinte: "vogando no rio, treze horas - Eu gosto desta solidão abundante do rio. Nada me agrada mais do que, sozinho, olhar o rio no pleno dia deserto (...) Isto não apenas neste Amazonas, mas sobretudo nos rios menores, como no Tietê, no Moji”" (Andrade, 1983, p. 76).

Entre as anotações sobre sua viagem ao Nordeste, há esta:

"Guanabara, 3 de dezembro, 19 horas Os amigos pouco a pouco se confundiram com o cais, o cais se confundiu com a cidade, o Manaus partiu. A noite vai cinzando água e ar. Entre os dois, quase negra, a língua crequenta e áspera da terra de Guanabara. As luzes salpicam o negrume dos morros amarrotados. Quando senão quando acorda 
mais uma. Junto do Hotel Glória e no quarteirão Serrador, os reflexos formam braseiros exatos. De-repente as praias se colorizam de luzes, uma por uma praia, puf,, puf?, puf! (...). A noite é definitiva e chega até mim" (Andrade, 1983, p. 209).

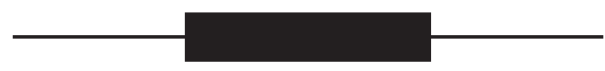

\section{Referências bibliográficas}

AGAMBEN, Giorgio. Estado de Exceção. Tradução de Iraci D. Poleti. São Paulo: Boitempo, 2004. . Homo Sacer: o poder soberano e a vida nua I. Tradução de Henrique Burigo. Belo Horizonte: Editora UFMG, 2007. . Profanações. Tradução e apresentação de Selvino J. Assmann. São Paulo: Boitempo, 2007.

ANDRADE, Mário de. A lição do amigo: cartas de Mário de Andrade a Carlos Drummond de Andrade. Rio de Janeiro: José Olímpio, 1982.

. Cartas de Mário de Andrade a Murilo Miranda. Rio de Janeiro: Nova Fronteira, 1981.

. Correspondente contumaz: cartas a Pedro Nava. Rio de Janeiro: Nova Fronteira, 1982.

. "O movimento modernista". In: Aspectos da literatura brasileira. São Paulo: Martins Editora, 1974 .

. O turista aprendiz. Estabelecimento de texto, introdução e notas de Telê Porto Ancona Lopez. São Paulo: Duas Cidades, 1983.

. Poesias completas. São Paulo/Belo Horizonte: Editora da Universidade de São Paulo/Itatiaia, 1987.

AUMONT, Jacques. O olho interminável [cinema e pintura]. Tradução de Eloísa Araújo Ribeiro. São Paulo: Cosac \& Naify, 2004.

BARTHES, Roland. O Neutro. Texto estabelecido, anotado e apresentado por Thomas Clerc; tradução de Ivone Castillo Benedetti. São Paulo: Martins Fontes, 2003.

BENJAMIN, Walter. "Sur la peinture, ou: Signe et Tache”. In: Oeuvres I. Paris: Gallimard, 2000.

Passagens. Organização da edição brasileira de Willi Bolle, colaboração de Olgária Matos; Tradução do alemão de Irene Aron e tradução do francês de Cleonice Paes Barreto; revisão técnica de Patrícia de Freitas Camargo. Belo Horizonte: Editora UFMG; São Paulo: Imprensa Oficial do Estado de São Paulo, 2006.

. Rua de mão única. Obras escolhidas II. Tradução de Rubens Rodrigues Torres Filho e José Carlos Martins Barbosa. São Paulo: Brasiliense, 1987. 
DELEUZE,Gilles. A dobra: Leibniz e o barroco. Tradução de Luiz B.L. Orlandi. Campinas, São Paulo: Papirus, 1991.

DIDI-HUBERMAN, Georges. Devant le temps. Paris: Les Éditions de Minuit, 2000. . O que vemos, o que nos olha. Tradução de Paulo Neves. São Paulo: Editora 34, 1998.

FERNANDES, Silvia \& AUDIO, Roberto (orgs.). BR-3. São Paulo: Perspectiva: Editora da Universidade de São Paulo, 2006.

FOUCAULT, Michel. História da sexualidade I: a vontade de saber. Tradução de Maria Thereza Albuquerque e J. A. Guilhon Albuquerque. Rio de Janeiro: Edições Graal, 1979. . "Outros espaços". In: Ditos e Escritos III. Rio de Janeiro: Forense Universitária, 2005.

GOMBRICH, E. H. La imagen y el ojo: nuevos estudio sobre la psicologia de la representación pictórica. Madrid: Alianza Editorial, 1987.

ISER, Wolfgang. O fictício e o imaginário: perspectivas de uma antropologia Literária. Tradução de Johannes Kretschmer. Rio de Janeiro: EdUERJ, 1996.

ROCHA, João César de Castro (org.). Teoria da ficção: indagações à obra de Wolfgang Iser. Tradução de Bluma Waddington Vilar, João César de Castro Rocha. Rio de Janeiro: EdUERJ, 1999.

SÜSSEKIND, Flora."Predomínio do negro". In: A voz e a série. Rio de Janeiro: Sette Letras; Belo Horizonte: Editora UFMG, 1998. 